\title{
Özel Gereksinimli Çocuğa Sahip Ebeveynler ile Tipik Gelişim Gösteren Çocuğa Sahip Ebeveynlerin Stres ve Yaşam Doyum Düzeylerinin İncelenmesi
}

DOI: $10.26466 /$ opus. 832440

\author{
$\underline{\text { Serkan Cengiz* }}$ - Melike Nebioğlu Yıldız ${ }^{* *}$ - Adem Peker *** \\ ${ }^{*}$ Uzman, Milli Eğitim Bakanlığ 1 \\ E-Posta: srkn_cngz_25@hotmail.com \\ ORCID: 0000-0001-9070-6338 \\ ** Doç.Dr., Mersin Üniversitesi, Tıp Fakültesi / Ruh Sağlığı ve Hastalıkları Anabilim Dalı \\ E-Posta: melikenebioglu@mersin.edu.tr \\ ORCID: 0000-0002-5901-0364 \\ ***Doç.Dr., Atatürk Üniversitesi Kazım Karabekir Eğitim Fakültesi / \\ Rehberlik ve Psikolojik Danışmanlık Anabilim Dalı \\ E-Posta: adem.peker@atauni.edu.tr \\ ORCID: $\underline{0000-0002-3594-9166}$
}

\section{Öz}

Araştırmada özel gereksinimli çocuğa sahip ebeveynler ile tipik gelişim gösteren çocuğa sahip ebeveynlerin stres ve yaşam doyum düzeylerinin karşılaştırılması amaçlanmıştır. Araştırmanın çalışma grubu Erzurum il merkezinde farklı özel eğitim ve rehabilitasyon merkezinde öğrenim gören 117'si özel gereksinimi olan, 148'i tipik gelişim gösteren çocuğa sahip kolayda örnekleme yöntemi ile seçilmiş 265 ebeveynden oluşmaktadır. Çalışma grubuna ait veriler anne baba stres ölçeği ve yaşam doyum ölçĕ̆i kullanılarak elde edilmiştir. Ebeveynlerin stres ve yaşam doyumlarına ilişkin ölçeklerden aldıkları puanlar bağımsız örneklemler için t-testi uygulanarak analiz edilmiştir. Sonrasında ortaya çıkan t-testi sonuçlarının etki değerleri hesaplanmıştır. İki grup arasındaki stres puanları kıyaslandığında özel ihtiyacı bulunan çocuklarm ebeveynlerinin stres puanları diğer gruptaki ebeveynlere göre daha yüksek, yaşam doyumu puanları ise daha düşük bulunmuştur. Gruplar arası farkın büyüklüğ̈̈̈nü belirlemek amacıyla yapılan etki değeri hesaplaması sonucunda stres ve yaşam doyumunun ebeveynler üzerinde yüksek düzeyde etkiye sahip olduğu görülmüştür. Araştırma bulgu sonuçlarından yola çıkılarak benzer araştırmaların daha büyük çalışma gruplarıyla gerçekleştirilmesi, tipik gelişim gösteren çocuğa sahip ebeveynler ile özel gereksinimli çocuğa sahip ebeveynlerin karşılaştırıldı̆̆ı betimsel ve deneysel araştırmalar yapılması önerilmiştir.

Anahtar Kelimeler: Özel Gereksinim, Tipik Gelişim, Ebeveyn, Stres, Yaşam Doyumu 
ISSN: 2528-9527

E-ISSN : 2528-9535

Yıl Year: 11

Cilt Volume: 17

Sayı Issue:36

\title{
Examination of Stress and Life Satisfaction Levels of Parents with Special Needs Children and Parents with Typical Developing Children
}

\begin{abstract}
The aim of the study was to compare the stress and life satisfaction levels of parents of children with special needs and parents of children with healthy development. The study group of the study consists of 265 parents selected by convenience sampling method, 117 of whom have special needs and 148 children with typical development, studying in different special education and rehabilitation centers in Erzurum. Data from the study group were obtained using the parent stress scale and the life satisfaction scale. The scores that parents received from the stress and life satisfaction scales were analyzed by applying a $t$-test for independent samples. After that the effect values of the resulting $t$-test results were calculated. Compared to the stress scores between the two groups, the stress scores of parents of children with special needs were higher than those of parents in the other group, and the life satisfaction scores were lower. As a result of the effect value calculation performed to determine the size of the difference between the groups, stress and life satisfaction were found to have a high level of impact on the parents. Based on the findings of the research, it was suggested that similar studies should be carried out with larger study groups, and descriptive and experimental studies in which parents were compared.
\end{abstract}

Keywords: Special needs, typical development, parent, life satisfaction 


\section{Giriş}

Birçok ebeveyn çocuk sahibi olmayı yaşanabilecek en güzel duygulardan birisi olarak değerlendirir. Arzulanan duyguları yaşamak için çocuk sahibi olmaya karar veren aileler bu kararla birlikte yaşamlarına birçok değişiklik ve yeniliği de dahil etmiş olurlar. Heyecan içeresinde çocuklarının dünyaya gelmesini bekleyen anne babalar onların yaşamasında ve gelişiminde önemli bir etkiye sahiptir. Aileler taşıdıkları bu sorumluluktan hareketle çocuklarının ihtiyaçlarını karşılamak adına ellerindeki olanaklarını en üst düzeyde kullanmaya çabalarlar. Çoğu aile çocuklarının farklı türde ihtiyaçlarını karşılamada bazı sorunlarla karşılaşmaktadır. Tipik gelişim gösteren çocuğa sahip ebeveynlerin, ihtiyaçları yerine getirmede aşırı zorluk yaşamadığı söylenebilir. Ancak özel gereksinimli çocuğa sahip ebeveynler olası sorunların yanında çocuklarının engel durumuna ilişkin karmaşık duygu ve düşüncelere bağlı oluşan stresle de mücadele etmektedir (Yıldırım ve Conk, 2005).

Stres, bireyin yaşantısında değişiklik gösteren bir durum karşısında hissetmiş olduğu gerilimdir (Gökler ve Işıtan, 2012). Özel ve Karabulut (2018) stresi, organizmanın çevreyle gerçekleşen etkileşimi sonrası psikolojik ve fizyolojik uyumunun bozulması olarak tanımlamıştır. Ebeveynlik stresi ise anne babaların, çocuk sahibi olmanın gerektirdiği görevlere karşı sorumluluklarını yerine getirmede yaşadıkları fizyolojik ve psikolojik tepkilerden oluşan bir süreçtir (Aydoğan ve Özbay, 2017). Ebeveynlerin yaşamış oldukları stres durumu birçok farklı durumdan etkilenmektedir (Azar, Megan ve Goslin, 2008). Yaşama ait kaynakların sınırlı olması, sosyo ekonomik koşulların yetersiz olması, bir ebeveyn olarak kendini yetkin görme düzeyini düşük olması, çok çocuğa sahip olma gibi etkenler ebeveynlik stresini artırmaktadır (Aber, Jones ve Cohen, 2000, Arıcı Özcan ve Arslan, 2018). Ailelerin sağlıklı olarak beklediği çocuklarını özel bir engelle dünyaya gelmesi de ebeveynlik stresini artıran önemli durumlardan birisidir (İlhan, 2017).

Çocuğun herhangi bir engel türüne sahip olarak dünyaya gelmesi aile üzerinde öncelikle şok ve inkar duygularını ortaya çıarmaktadır (Bjarnason, 2005). Bir süre sonra çocuğunun özel durumunu kabullenmeye başlayan anne babalar çocuklarının engel türüne göre eğitim ve gelişimlerini nasıl destekleyecekleri, onların bakımlarını daha iyi düzeye nasıl getirecekleri konusunda stres yaşamaktadır (Koçhan, 2019). İlerleyen süreçte çocukta engel durumundan kaynaklı sağlık ve davranış problemleri, aile yakınlarına çocuğun 
durumunu anlatmada zorluk ve ihtiyaçları gidermeye yönelik ekonomik endişeler var olan stresi daha da artırmaktadır (Avşaroğlu ve Okutan, 2018). Çok sayıda araştırma farklı özel gereksinime sahip çocukların anne babalarının sağlıklı gelişime sahip çocukların anne babalarına göre aile sistemindeki bozulmalara bağlı olarak daha yüksek düzeyde ebeveynlik stresi yaşadığını göstermektedir (Davis ve Carter, 2008; Lubiewska ve Derbis, 2016; Yıldırım, Aşlar ve Karakurt, 2016).

Ebeveynlik stresini ele alan yaklaşımlardan sistem yaklaşımına göre özel gereksinimi bulunan çocukların ebeveynlerinde artan yoğun stres bir süre sonra tüm aile üyeleri arasındaki ilişkilere olumsuz yansımaktadır (Bawalsah, 2016). Bu durum anne, babaların kendi aralarında çatı̧̧malarına, iş ve sosyal yaşamlarında farklı sorunlar yaşamalarına neden olmaktadır (Köksal ve Kabasal, 2012). Stresle başa çıkma gücü zayıf olan bazı ebeveynler tüm bu olumsuz durum ve duyguların nedeni olarak çocuklarını görmeye başlayarak çocuğu reddetmeye yönelik tutum sergilemektedir (Dervishaliaj, 2013). Yapılan araştırmalarda çocuğunda özel gereksinim tanısı bulunan stres düzeyi yüksek ebeveynlerin, sağlıklı gelişim gösteren çocuğun ebeveynlerine göre sosyal çevresiyle yakınlık kurma (Özmen ve Çetinkaya, 2012), onların eleştirilerine tolerans gösterme (İnal, 2012) ve alınan kararlara uyumlu tutum sergileme becerilerinde (Cagran ve Schmidt, 2011) daha zayıf oldukları görülmüştür.

Özel gereksinimli çocuğa sahip ebeyenlerde çocukların bakımı, eğitim, tedavi ve yetiştirilmesi gibi konularda karşılaşılan sorunlar yaşam doyumlarını da olumsuz etkilemektedir (Aktan, Orakcı ve Durnall, 2020; Misura ve Memisevic 2017). Yaşam doyumu, bireyin yaşam koşullarına ilişkin fırsatlar ve beklentileri karşılaştırılmasına dayanan bilişsel bir yargıdır (Cho ve Hong, 2013). Yaşam doyumuna yönelik geliştirilen sosyal karşılaştırma teorisine göre kendilerini diğerlerinden daha iyi yargılayan ebeveynlerin yaşamdan aldıkları memnuniyet daha yüksektir (Kaner, 2004). Engelli çocuğa sahip ebeveynlerin sorumlu olduğu rollerdeki stresli geçişler ve zorlu yaşam koşullarına bağlı ortaya çıkan olumsuz duygular yaşamda memnuniyet algılamalarını olumsuz etkilemektedir (Darling, Senatore ve Strachan, 2017). Çeşitli sorunlar ve olumsuz duygular karşısında başa çıkma kabiliyeti ve sosyal desteği zayıflayan ebeveynler, yaşamlarındaki olumsuz algılara yönelik pozitif tutum geliştirmekte zorlanabilmektedir. Çocuğunun özel durumuna ilişkin yakın çevreden yeterli desteği görmeyen ve duygusal sorunlarla başa çıma 
gücü zayıflayan ebeveynlerin yaşamdan elde ettiği haz düzeyi de oldukça düşüktür (Altuğ Özsoy, Özkahraman ve Çallı, 2006). Fung ve Rogge (2007) çocuğunun özel durumuna bağlı olarak duygusal ve sosyal anlamda yaşam doyumu zayıf ebeveyenlerin, evlilik memnuniyetlerinin düşük olduğunu belirtmiştir. Yine Wang, Huang ve Kong (2017) bu ailelerde kişisel ve ortak problemleri çözme becerilerindeki zayıflığın çiftler arasında mutsuzluğa yol açtı̆̆ını ileri sürmüştür.

Özel eğitime muhtaç çocuklara sahip ebeveynler stres ve diğer birçok olumsuz duygusal problemin anlamlandırma ve yorumlanmasında zorluk yaşayabilmektedir. Bu nedenle günlük yaşamında olumsuz duygularla başa çıkmada faydalı olabilecek bilgileri sunma ve psikoterapötik yaklaşımları içeren çalışmalarda bulunma, maruz kalınan duygularla baş etmede etkili olabilmektedir. Bu bilgiler doğrultusunda araştırmada özel gereksinimli çocuğa sahip ebeveynler ile normal gelişim gösteren çocuğa sahip ebeveynlerin stres ve yaşam doyumlarını karşılaştırarak incelemek amaçlanmıştır. Bu genel amaç doğrultusunda aşağıdaki sorulara cevap aranmıştır:

1. Özel gereksinimli çocuğa sahip ebevynler ile tipik gelişim gösteren çocuğa sahip ebeveynlerin stres puanları arasinda anlamlı fark var m1dir?

2. Özel gereksinimli çocuğa sahip ebevynler ile tipik gelişim gösteren çocuğa sahip ebeveynlerin yaşam doyumu puanları arasında anlamlı fark var midır?

\section{Yöntem}

\section{Çalışma Grubu}

Araştırmanın çalışma grubunu Erzurum il merkezinde farklı özel eğitim ve rehabilitasyon merkezinde öğrenim gören 117'si özel gereksinimi olan, 148'i tipik gelişim gösteren çocuğa sahip kolayda örnekleme yöntemi ile seçilmiş 265 ebeveyn oluşturmuştur. Kolayda örnekleme yöntemi, seçilecek örnek kesimin araştırmacının yargılarınca belirlendiği örnekleme yöntemidir (Haş1loğlu, Baran ve Aydın, 2015). Bu örneklemede, ana kütleden veriler en kolay, hızlı, ekonomik şekilde toplandığından araştırmayıca zaman ve uygulanabilirlik açısından kolaylık sağlamaktadır. 


\section{Veri Toplama Araçları}

Anne Baba Stres Ölçeği: Ebeveynlerin günlük yaşamlarında çocuklarına ilişkin yaşadıkları stresi ortaya çıkarmak için Özmen Kaymak ve Özmen (2012) tarafından geliştirilmiştir. Ölçek toplam 16 madde ve tek alt boyuttan oluşmaktadır.

5 li likert tipinde hazırlanan ölçekte "(1) kesinlikle katılmıyorum", (2) "katılmıyorum", (3) "kararsızım", (4) "katllyorum" ve (5) "kesinlikle katılıyorum" şeklinde derecelendirilmektedir. Anne baba stres ölçeğine ilişkin örnek bir madde; "Hayal ettiğim gibi bir anne/baba olamadığımı düşünüyorum". Ölçekten alınan puanların yükselmesi anne baba stres düzeyinin arttığını göstermektedir. Ölçeğin iç tutarlık güvenirliği için hesaplanan Cronbach Alfa değeri .85'dir. Bu çalışmada ölçeğin iç tutarlık güvenirlik katsayısı ise .90 olarak bulunmuştur.

Yaşam Doyum Ölçeği: Ölçeğin orjinal hali Diener, Emmons, Larsen ve Griffin (1985) tarafından geliştirilmiştir. Ölçeğin uyarlanma çalışmaları ise Dağlı ve Baysal (2016) tarafından gerçekleştirilmiştir. Ölçekte toplam 5 soru bulunmaktadır. 5 li likert tipinde hazırlanan ölçekte "(1) hiç katılmıyorum", (2) "çok az katılmıyorum", (3) "orta düzeyde katılıyorum", (4) “büyük oranda katıllyorum" ve (5) "tamamen katıliyorum" şeklinde derecelendirilmektedir. Ölçeğe ilişkin örnek bir madde; "Yaşamımdan memnunum". Ölçek tek faktörlü yapıdan oluşmaktadır. Ölçeğin iç tutarlık güvenirliği için hesaplanan Cronbach Alfa değeri .88' dir. Bu çalışmada ölçeğin iç tutarlık güvenirlik katsayısı ise .87 olarak bulunmuştur.

\section{Etik İşlem}

Çalışmaya başlamadan Atatürk Üniversitesi Eğitim Bilimleri Etik Kurulu Başkanlığı'ndan araştırma yapma izni alındı (Tarih: 12.11.2020, say1:56785782-050.02.04-E.2000285180).

\section{Veri Toplama Süreci}

Araştırma verileri covid-19 salgınından dolayı, Google Formlar üzerinden hazırlanarak araştırma çalışma grubuna uygulanmıştır. Yakutiye Rehberlik ve Araştırma Merkezi'ne kayıtlı öğrencisi bulunan velilere araştırma içeriğinden bahsedilerek gönüllü olan kişilerin araştırmaya katılımı sağlanmıştır. 


\section{Verilerin Analizi}

Araştırmada tipik ve özel gereksinimli çocukların ebeveynlerinin stres ve yaşam doyumu puan ortalamalarının gruplar arasındaki farklılık durumu bağımsız örneklemlerde $t$ testi kullanılarak incelenmiştir. Gruplar arası farkın büyüklüğünü hesaplamak amacıyla stres ve yaşam doyumu puanlarının etki değeri hesaplanmıştır. Tüm bu analizleri yapabilmek adına araştırma veri setinin normallik değerlerine tablo 1'de bakılmıştır.

Tablo 1. Araştırmada kullanılan değişkenlere ilişkin normallik değerleri

\begin{tabular}{|c|c|c|c|c|c|c|c|}
\hline & A.Ortalama & Standart Sapma & \multicolumn{2}{|c|}{ Çarpıklık } & \multicolumn{3}{|l|}{ Basıklık } \\
\hline Değişkenler & İstatistik & İstatistik & İstatistik & S.H. & İstatistik & S.H. & \\
\hline Stres & 28.00 & 8.71 & .82 & .15 & & .20 & .29 \\
\hline Yaşam Doyumu & 16.30 & 5.44 & -.14 & .15 & -.95 & & .29 \\
\hline $\mathbf{N}$ & & & 265 & & & & \\
\hline
\end{tabular}

Tablo 1'de verilerin çarpıklık ve basıklık değerlerinin +2 ila -2 arasında olduğu görülmektedir. Bu sonuç doğrultusunda araştırma değişkenlerinin normal dağılım gösterdiği söylenebilir (Tabachnick ve Fidell, 2013).

\section{Bulgular}

\section{Ebeveynlerin Stres Puanlarna İlişkin t Testi Sonuçlan}

Tablo 2. Ebeveynlerin stres puanlarna ilişkin t testi sonuçlan

\begin{tabular}{|c|c|c|c|c|c|c|c|}
\hline Değişken & Cinsiyet & $\mathbf{N}$ & $\overline{\mathbf{x}}$ & S.s & $\mathbf{t}$ & p & $d$ \\
\hline \multirow[t]{2}{*}{ Stres } & Tipik Gelişim Gösteren Çocuğa Sahip Olan Aileler & 117 & 24.42 & 6.64 & \multirow{2}{*}{-6.38} & \multirow{2}{*}{.001} & \multirow{2}{*}{.80} \\
\hline & Özel Gereksinimli Çocuğa Sahip Aileler & 148 & 30.83 & 9.13 & & & \\
\hline
\end{tabular}

Tablo 2 incelendiğinde tipik gelişim gösteren çocuğa sahip ebeveynler ile özel gereksinimli çocuğa sahip ebeyenlerin stres puanlarının istatistiksel olarak anlamlı farklılaştığı görülmektedir $(\mathrm{t}(265)=6.38, \mathrm{sd}=263, \mathrm{p}=.001)$. Bu sonuca göre özel gereksinimli çocuğa sahip ailelerin stres puanlarının $(\bar{X}=30.83$, $\mathrm{S} . \mathrm{S}=9.13)$, tipik gelişim gösteren çocuğa sahip ailelerin stres puanlarından $(\overline{\mathrm{X}}=24.42$, S.s=6.64) daha yüksektir. Etki büyüklüğü açısından özel gereksinimli çocuğa sahip olma durumunun ebeveynlerin stres düzeyleri üzerinde yüksek bir etkiye $(d=.80)$ sahip olduğu söylenebilir (Cohen, 1988). 


\section{Ebeveynlerin Yaşam Doyumlarna İlişkin t Testi Sonuçlan}

Tablo 3. Ebeveynlerin yaşam doyumu puanlarna ilişkin t testi sonuçları

\begin{tabular}{|c|c|c|c|c|c|c|c|}
\hline Değişken & Cinsiyet & $\mathbf{N}$ & $\overline{\mathbf{X}}$ & S.s & $\mathbf{t}$ & $\mathrm{p}$ & $d$ \\
\hline Yaşam & Tipik Gelişim Gösteren Çocuğa Sahip Olan Aileler & 117 & 18.10 & 4.85 & \multirow{2}{*}{4.98} & \multirow{2}{*}{.004} & \multirow{2}{*}{.62} \\
\hline Doyumu & Özel Gereksinimli Çocuğa Sahip Aileler & 148 & 14.88 & 5.49 & & & \\
\hline
\end{tabular}

Tablo 3 incelendiğinde tipik gelişim gösteren çocuğa sahip ebeveynler ile özel gereksinimli çocuğa sahip ebeyenlerin yaşam doyumu puanlarının istatistiksel olarak anlamlı farklılaştığ1 görülmektedir $(t(265)=-6.38$, sd=263, $\mathrm{p}=.001)$. Bu sonuca göre özel gereksinimli çocuğa sahip ailelerin yaşam doyumu puanlarının ( $\bar{X}=14.88$, S.s $=5.49)$, tipik gelişim gösteren çocuğa sahip ailelerin yaşam doyumu puanlarından ( $\bar{X}=18.10, S . s=4.85)$ daha az olduğu söylenebilir. Etki büyüklüğü açısından özel gereksinimli çocuğa sahip olma durumunun ebeveynlerin yaşam doyumları üzerinde yüksek düzeyde bir etkiye ( $d=.62)$ sahip olduğu söylenebilir.

\section{Tartışma ve Sonuç}

Araştırmanın bulgularının ilkinde, özel gereksinimli çocuğa sahip ebeveynlerin stres puanlarının tipik gelişim gösteren çocuğa sahip ebeveynlere göre daha yüksek olduğu ve çocukların farklı gelişim gösterme durumunun ebeveynlerin stres durumları üzerinde yüksek bir etkiye sahip olduğu bulunmuştur. Anne babalar dünyaya getirmiş oldukları çocuklarına yönelik farklı konularda sorumluluklar taşımaktadır. Özel gereksinimli çocukların ebeveynleri bu sorumlulukların yanında günlük yaşamlarında başta stres olmak üzere farklı duygusal sorunlar yaşamaktadır (Uskun ve Gündoğar, 2010). Özellikle de çocuklarının yaşamlarını organize etmede normal gelişim gösteren çocuğa sahip ebeveynlere göre yoğun ekonomik ve psikolojik güç harcayan bu aileler, kendilerini daha fazla stresli hissetmektedir (Cengiz, Baş ve Elaltunkara, 2016). Yapılan birçok araştırma özel gereksinimli çocukların ebeveynlerinde stresin, normal olarak gelişmekte olan çocukların ebeveynlerine göre daha fazla olduğunu göstermektedir (Akça ve Özyürek, 2019; Feizi, Najmi, Salesi, Chorami ve Hoveidafar, 2014; Turan Gürhopur ve İşler Dalgıç, 2017; Ritzema ve Sladeczek, 2011). Plant ve Sanders (2007) uyumsuz davranışlar sergileyen mental yetersizliği bulunan çocukların ebeveynlerinin diğer ailelere göre daha fazla stres yaşadıklarını belirtmiştir. Sabih ve Sajid (2008) 
otizm tanılı çocuğa sahip ailelerin, çocuklarının yetişme düzeylerini değerlendirmede yaşadıkları zorluklara bağlı olarak yoğun stres yaşadıklarını ifade etmiştir. Padden ve James (2017) yaptıkları araştırmada, otizm tanısı almış çocuğa sahip ebeveynlerde, sosyal destek ve başa çkma stratejilerinde azalmaya bağlı olarak yoğun stres tepkilerine rastlamıştır.

Özel durumu olan çocuklar farklı yaşam alanlarında ihtiyaçlarını ebeveynleri sayesinde gidermektedir. Özel ihtiyacı bulunan çocuğa sahip aileler kişisel, sosyal ve ekonomik tüm kapasitelerini kullanarak çocuklarının iyi oluşunu artırmaya çabalamaktadır. Ancak engel durumunun belirgin olmayan doğası ebeveynlerin zaman zaman yetkinliklerinin sorgulanmasına yol açabilmektedir. Çocuğun gelişiminden kaynaklanan bu tip zorluklar ebeveynleri stres kaynaklı kriz yaşantılarına maruz bırakmakla birlikte yaşam kalitelerini da olumsuz etkilemektedir (Habib Ayaz, Asmet ve Naseem, 2016).

Araştırmanın bir diğer bulgu sonucunda özel gereksinimli çocuğa sahip ebeveynlerin, tipik gelişim gösteren çocuğa sahip ebeveynlere göre yaşam doyumu puanlarının daha düşük olduğu belirlenmiştir. Ayrıca özel gereksinimli çocuğa sahip olma durumunun ebeveynlerin yaşam doyumları üzerinde yüksek bir etkiye sahip olduğu bulunumuştur. Yapılan araştırmalar incelendiğinde özel gereksinimli çocuğa sahip ebeveynlerin yaşam doyumlarının birçok olumsuz psikolojik parametreden etkilendiği görülmektedir (Cappe, Wolff, Bobet ve Adrien, 2011; Çattık ve Aksoy, 2018). Özellikle ebeveynlerin çocuklarına etkili eğitim kaynaklarını sağlama, çocuğun toplumun kültürel yaşamına uyumu ve çevreyle sosyal temaslar kurmasına ilişkin endişeleri farklı olumsuz duygulara yol açarak ailelerin yaşam memnuniyetlerini düşürmektedir (Kahriman ve Bayat, 2008; Millere ve Senkane, 2014). Aysan ve Özben (2007) özel gereksinimi olan çocuğa sahip annelerin, sağlıklı çocuğu olan annelere göre depresyon düzeylerini daha yüksek, yaşam doyumlarını ise daha düşük düzeyde bulmuştur. Juhasova (2015) sosyo-ekonomik yetersizliklere bağlı olarak çocuklarının ihtiyaçlarını karşılayamayan ailelerin mutluluk ve yaşam doyum düzeylerinin düşük olduğunu belirtmiştir. Şener (2009) serebral palsi tanılı çocuğa sahip annelerin stresle başa çıkma ve denetim odaklarındaki zayıflamaya bağlı olarak yaşam doyumu düzeylerinin de gerilediğini ortaya çıkarmıştır. Allen ve Marshall (2010) mental retardasyon tanılı çocuğa sahip ebeveynlerin yaşam doyumlarını diğer ailelerle eşit düzeye getirmede psikolojik ve sosyal desteği içeren çalışmalara daha 
fazla ihtiyaç duyduklarını tespit etmiştir. Benzer araştırmada Benson ve Karlof (2009) çeşitli davranış sorunları bulunan otizm tanılı çocuğa sahip stresli ebeveynlerin yaşam memnuniyetlerini diğer ebeveynlere göre daha düşük bulmuştur.

Özel gereksinimli çocuğa sahip ailelerin çocuğu ile birlikteliği doğumla başlayarak ömür boyu devam eden uzun bir süreci kapsamaktadır. Bu sürecin aynı zamanda ebeveyenler tarafından başa çıkılması gereken bazı sorunlar içeren zorlu bir süreç olduğu söylenebilir. Çocuğun dünyaya gelmesiyle birlikte durumunu kabul etme ve uyum sağlama sonrası bakım, büyüme, eğitim ve tedavi gibi konularda yaşanabilecek güçlükler ailede duygusal problemlere neden olabilmektedir. Çocuklarının bağımsız yaşayabilme becerilerine yönelik aşırı koruyucu tutum sergileyen aileler yoğun stres altında bu tarz yaklaşımda bulunabilmektedir. Çocuğun yaşadığı güçlüklere karşı aşırı duygusal ve sosyal yüklemeler yapan ebeveynler tüm sorunları çözmede kendilerine bazı olumsuz koşullanmalar geliştirebilmektedir. Yaşamının her alanında bu sorumluluğu aşırı hisseden anne babalar duygusal anlamda stres ve azalan bir yaşam doyumu ile mücadele içerisine girebilmektedir. Ebeveynlerin yaşamış olduğu duygusal çatışma ve problemlerin çözümlenmesi çocuğun ihtiyaçlarının karşılanmasının yanı sıra sağlıklı büyütülmesi ve gelişimi adına önemlidir. Bunlardan ayrı olarak araştırmanın bazı sınırlııkları bulunmaktadır;

- Araştırma örneklemi Erzurum il merkezinde bulunan rehabilitasyon merkezlerine devam eden özel gereksinimli çocukların ebeveynleri ile tipik gelişim gösteren çocukların ebeveynleriyle sınırlıdır. Araştırmanın genellenebilirliğini artırmak adına araştırmanın daha fazla katılımcıyla uygulanması önerilebilir.

- Engelli çocuğa sahip olan ve olmayan ebeveynlerin stres düzeyleri ile yaşam doyumları arasındaki anlamlı farklılaşma "Ebeveyn Stres Ölçeği" ve "Yaşam Doyumu Ölçeği'nin"ölçtüğü nitelik ve özelliklerle sınırlıdır. Benzer araştırmanın nitel veya karma yöntemle tekrar yapılması önerilebilir.

- Farklı araştırmalarda iyi oluş, depresyon, başa çıkma tarzları gibi farklı değişkenler kullanılarak tipik ve özel gereksinimli çocuğa sahip olan ailelerin ruh sağlığına ilişkin durumları incelenebilir. 
EXTENDED ABSTRACT

\title{
Examination of Stress and Life Satisfaction Levels of Parents with Special Needs Children and Parents with Typical Developing Children
}

\author{
Serkan Cengiz - Melike Nebioğlu Yıldız - Adem Peker \\ Ministry of Education-Mersin University-Atatürk University
}

Parents who are excitedly waiting for their children to be born have an important effect on their life and development. Based on this responsibility, families try to use their facilities at the highest level in order to meet the needs of their children. We can be said that parents with typically developing children do not have extreme difficulty in fulfilling their needs. However parents with children with special needs struggle with the stress they experience regarding the special situation of their children along with some problems (Yıldirım and Conk, 2005).

Stress is the tension people feel in the face of a changing situation (Gökler and Işitan, 2012).Parental stress is a process that consists of the physiological and psychological reactions that parents experience in fulfilling their responsibilities against the duties of having a child (Aydoğan ve Özbay, 2017). Factors such as limited resources for life, insufficient socio-economic conditions, low level of self-competence as a parent, and having many children increase parenting stress (Aber, Jones and Cohen, 2000, Arıc1 Özcan and Arslan, 2018). Children of families who are born with a special disability are one of the situations that increase the stress of parenthood (Illhan, 2017). Many studies show that the parents of children with different special needs experience higher levels of parental stress due to the deterioration in the family system than their parents of children with healthy development (Davis and Carter, 2008; Lubiewska and Derbis, 2016; Yıldırım, Aş1lar and Karakurt, 2016).

The problems faced by parents with children with special needs in matters such as care, education, treatment and upbringing of children also negatively affect their life satisfaction (Aktan, Orakc1 and Durnalı, 2020; Misura and Memisevic 2017). Life satisfaction is a cognitive judgment based on the comparison of opportunities and expectations of an individual's living conditions 
(Cho ve Hong, 2013). Parents with children in need of special education have difficulty in interpreting and interpreting stress and many other negative emotional problems. For this reason, presenting information that may be useful in dealing with negative emotions in daily life and conducting studies involving psychotherapeutic approaches can be effective in coping with the emotions exposed. In line with this information, it was aimed to examine whether there is a significant difference between the stress and life scores of parents with children with special needs and parents with children with typical development.

The study group of the study consisted of 265 parents selected by the convenience sampling method, 117 of whom had special needs and 148 children with typical development, studying in different special education and rehabilitation centers in Erzurum city center. Permission to conduct research was obtained from Atatürk University Educational Sciences Ethics Committee before starting the study. Research data were prepared on Google Forms and applied to the research working group due to the covid-19 outbreak. Participants were told about the research content and the volunteers were allowed to participate in the research.

Data from the study group were obtained using the parent stress scale and the life satisfaction scale. The difference between the groups in terms of stress and life satisfaction scores of the parents of typical and special needs children was analyzed using the independent samples $t$ test. In order to calculate the magnitude of the difference between groups, the effect value of stress and life satisfaction scores was calculated. In the first of the findings of the study, it was found that the stress scores of the parents with children with different developmental characteristics were higher than the parents with a child with typical development. It was also revealed that the different development of the children had a high effect on the stress situations of the parents. As a result of another finding of the study, it was determined that the life satisfaction scores of the parents with children with special needs were lower than the parents with children with typical development. It was also found that having a child with special needs has a high effect on parents' life satisfaction. The coexistence of families with children with special needs includes a long process that begins with birth and continues throughout life. This process can also be said to be a challenging one with some problems to be dealt with by parents. In line with the information obtained, it is recommended to conduct 
similar studies with more participants in future studies. The research can be repeated again using a qualitative or mixed method. By using different variables such as well-being, depression, and coping styles, the mental health status of families with typical and special needs children can be examined.

\section{Kaynakça / References}

Akça, F. ve Özyürek, A. (2019). Zihinsel yetersizlikten etkilenmiş ve normal gelişen çocuğa sahip ebeveynlerin sıkıntiyı tolere etme, depresyon, anksiyete ve stres düzeyleri. Journal of History Culture and Art Research, 8(1), 347-361

Aktan, O., Orakc, Ş. ve Durnalı, M. (2020). Investigation of the relationship between burnout, life satisfaction and quality of life in parents of children with disabilities. European Journal of Special Needs Education, 1-17

Allen, D. ve Marshall, E. S. (2010). Spirituality as a coping resource for African American parents of chronically ill children. American Journal of Maternal Health Nursing, $35,232-237$

Altuğ Özsoy, S., Özkahraman, Ş. veÇalll, F. (2006). Zihinsel engelliçocuk sahibi ailelerin yaşadıkları güçlüklerin incelenmesi. Aile ve Toplum Dergisi, 3(9), 69-79

Avşaroğlu, S. ve Okutan, H. (2018). Zihin engelli çocuğu olan ailelerin yaşam doyumları, iyimserlik ve psikolojik belirti düzeylerinin incelenmesi. Manas Sosyal Araştırmalar Dergisi, 7(1), 59-76

Aydoğan, D. ve Özbay, Y. (2017). Ebeveynlik Stres Ölçeği geçerlik ve güvenirlik çalışması. Uluslararası Erken Çocukluk Ĕ̆itimi Çalı̧̧maları Dergisi, 2(2), 24-38

Aysan, F. ve Özben, Ş. (2007). Engelli çocuğu olan anne babaların yaşam kalitelerine ilişkin değişkenlerin incelenmesi. Dokuz Eylül Üniversitesi Buca Eğitim Fakültesi Dergisi, 22, 1-6

Azar, S. T., Reitz, E. B. ve Goslin, M. C. (2008). Mothering: Thinking is part of the job description: Application of cognitive views to understanding maladaptive parenting and doing intervention and prevention work. Journal of Applied Developmental Psychology, 29, 295-304.

Baş, B. A. (2018). Özel gereksinimli çocuğa sahip ebeveynler ile normal gelişim gösteren çocuğa sahip ebeveynlerin yalnzllk düzeyleri ve eolilik doyumu ile iliskilerinin incelenmesi. Yüksek lisans tezi. Yükseköğretim Kurulu Tez Merkezi'nden edinilmiştir. (Tez No. 541480)

Bawalsah, A. J. (2016). Stress and coping strategies in parents of children with physical, mental, and hearing disabilities in jordan. International Journal of Education, 8(1), $1-22$. 
Benson, P. R. ve Karlof, K. L. (2009). Anger, stress proliferation, and depressed mood among parents of children with ASD: A longitudinal replication. Journal of $A u-$ tism and Developmental Disorders, 39, 350-362

Bjarnason, D. S. (2005). Disability studies and their importance for special education professionals. Nordic Studies in Education, 25(4), 339-356

Bursal, M. (2019). Spss ile temel veri analizleri. Anı Yayıncilik: Ankara

Cagran, B. ve Schmidt, M. (2011). Attitudes of Slovene teachers towards the inclusion of pupils with different types of special needs in primary school. Educational Studies, 37(2), 171-195

Cappe, E., Wolff, M., Bobet, R. ve Adrien, J. L. (2011). Quality of life: a key variable to consider in the evaluation of adjustment in parents of children with autism spectrum disorders and in the development of relevant support and assistance programmes. Quality of Life Research, 20(8), 1279-1294

Çattık, M. ve Aksoy, V. (2018). Gelişimsel yetersizliği olan çocukların ebeveynlerinin sosyal destek, öz yeterlik ve yaşam doyum düzeyleri arasındaki ilişkinin incelenmesi. Eğitim ve Bilim Dergisi, 43(195), 65-77

Cengiz Şarvan, Ş., Baş, M. ve Elaltunkara, C. (2016). Spor okullarına devam eden otizmli çocuğa sahip ebeveynlerin çocuk tabanlı değişkenlere göre stres vebaşa çıkma düzeylerinin incelenmesi, International Journal of Sport Culture and Science, 4(2), $439-453$

Cho, K. S. ve Hong, E. J. (2013). A path analysis of the variables related to the quality of life of mothers with disabled children in Korea. Stress and Health, 29, 229-239

Cohen J, (1988). Statistical Power Analysis for the Behavioral Sciences, 2nd ed. Hillsdale, New Jersey: Erlbaum.

Dağlı, A. ve Baysal, N. (2016). Yaşam Doyumu Ölçeğinin Türkçe'ye uyarlanmass: Geçerlik ve güvenirlik çalışması. Elektronik Sosyal Bilimler Dergisi, 15(59), 12501262

Darling, C. A., Senatore, N. ve Strachan, J. (2012). Fathers of children with disabilities: Stress and life satisfaction. Stress and Health, 28, 269-278

Davis, N. O. ve Carter, A. S. (2008). Parenting stress in mothers and fathers of toddlers with autism spectrum disorders: Associations with child characteristics. Journal of autism and developmental disorders, 38(7), 1278

Dervishaliaj, E. (2013). Parental stress in families of children with disabilities: A literature review. Journal of Educational and Social Research, 3(7), 579-584 
Feizi, A., Najmi, B., Salesi, A., Chorami, M. ve Hoveidafar, R. (2014). Parenting stress among mothers of children with different physical, mental, and psychological problems. Journal of research in medical sciences: the official journal of Isfahan University of Medical Sciences, 19(2), 145-152

Funk, J. L. ve Rogge, R.D. (2007). Testing the ruler with item response theory: Increasing precision of measurement for relationship satisfaction with the couples satisfaction index. Journal of Family Psychology, 21(4), 572-83

Gökler, R. ve Isitan, I. (2012). Disease of the modern age: stress and its effects. Journal of History Culture and Art Research, 1(3), 154-168

Habib Ayaz H., Alia A. ve Sabahat N. (2016). Parental satisfaction with life and perceived social support of parents of children with intellectual disability. International Journal of Innovation and Scientific Research, 20(2), 398-402

Haşıloğlu, S.B., Baran, T. ve Aydın, O. (2015). Pazarlama araştırmalarındaki potansiyel problemlere yönelik bir araştırma: Kolayda örnekleme ve sıklık ifadeli ölçek maddeleri. Pamukkale İsletme ve Bilişim Yönetimi Dergisi, 2(1), 19-28

İlhan, T., (2017). Özel gereksinimli 3-6 yaş çocuklarının ebeveynlerinin stres düzeyleri ile rolleri arasındaki ilişki. Ankara Üniversitesi Ĕ̈itim Fakültesi Özel Ĕ̆itim Dergisi, 18(3), 383-400.

İnalı, Ç. (2012). Zihinsel velveya bedensel yetersizliği olan çocuğa sahip annelerin yaşam kalitesi ile tükenmişlik düzeylerine anneye verilen eğitimin ve danışmanlığın etkisi. Yüksek lisans tezi. Yükseköğretim Kurulu Tez Merkezi'nden edinilmiştir. (Tez No. 351177)

Juhasova, A. (2015). Comparison of quality of life of families with children with disability and families with children without disability. Social and Behavioral Sciences, 174, 3378-3384

Kabasakal, Z. ve Köksal, G. (2012). Zihinsel engelli çocukları olan ebeveynlerin yaşamlarında algıladıkları stresi yordayan faktörlerin incelenmesi. Buca Eğitim Fakültesi Dergisi, 32, 71-91

Kahriman, İ., \& Bayat, M. (2008). Özürlü çocuğa sahip ebeveynlerin yaşadıkları güçlükler ve algıladıkları sosyal destek düzeyleri. Öz-Veri Dergisi, 5(1), 11751194

Kaner, S. (2004). Engelli çocukları olan ana-babalarn stres, sosyal destek ve yaşam doyumlarmm incelenmesi. Ankara: Ankara Üniversitesi Bilimsel Araştırma Projeleri

Koçhan, A. (2019). Engelli çocuğa sahip ebeveynlerin stres düzeyi, stresle başa çikma tarzları, hastalı yükü algılan ve bilgece farkındalik düzeyleri arasındaki ilişkinin incelenmesi. (Yüksek lisans tezi). Yükseköğretim Kurulu Tez Merkezi'nden edinilmiştir. (Tez No. 541098) 
Love, H. R., Zagona, A. L., Kurth, J. A. ve Miller, A. L. (2017). Parents' experiences in educational decision making for children and youth with disabilities. Inclusion, 5(3), 158-172

Lubiewska, K. ve Derbis, R. (2016). Relations between parenting stress, attachment, and life satisfaction in mothers of adolescent children. Polish Journal of Applied Psychology, 14(2), 87-112

Millere, J. ve Senkane, S. (2014). Quality of life of families with children with disability in the area of physical wellbeing in Latvia. In SHS Web of Conferences (Vol. 10, p. 00026). EDP Sciences

Misura, A. K. ve Memisevic, H. (2017). Quality of life of parents of children with intellectual disabilities in Croatia. Journal of Educational and Social Research, 7(2), 4343

Özmen, D. ve Çetinkaya, A. (2012). Engelli çocuğa sahip ailelerin yaşadı̆̆ı sorunlar. Ege Üniversitesi Hemşirelik Fakültesi Dergisi 28(3), 35-49

Özmen Kaymak, S. veÖzmen, A. (2012). Anne Baba Stres Ölçeğinin geliştirilmesi. Milli Ĕ̈itim Dergisi, 42(196), 20-35

Özel, Y. ve Karabulut, B. A. (2018). Günlük yaşam ve stress yönetimi. Türkiye Sağllk Bilimleri ve Araştırmalan Dergisi, 1(1), 48-56

Padden, C. ve James, J. E. (2017). Stress among parents of children with and without autism spectrum disorder: a comparison involving physiological indicators and parent self-reports. Journal of developmental and Physical disabilities, 29(4), 567-586

Perry, C. L. ve Henry, M. J. (2009). Family and professional considerations for adoptive parents of children with special needs. Marriage E Family Review, 45(5), 538-565

Plant, K. M. ve Sanders, M. R. (2007). Predictors of care-giver stress in families of preschoolaged children with developmental disabilities. Journal of Intellectual Disability Research, 51(2) 109-124

Ritzema, A. M. ve Sladeczek I. E. (2011). Stress in parents of Children with Developmental Disabilities over Time. Journal on Developmental Disabilities. 17(2), 21-34

Sabih, F. ve Sajid, W. B. (2008). There is significant stress among parents having children with autism. Rawal Medical Journal, 33(2), 214-216

Şener, F. (2009). 5-14 yaş Serebral Palsi'li çocuğa sahip annelerin stresle başa çikma tarzlari ve denetim odaği arasindaki ilişkinin incelenmesi. (Yüksek lisans Tezi). Yükseköğretim Kurulu Tez Merkezi'nden edinilmiştir. (Tez numarası:254011)

Tabachnick, B. G. ve Fidell, L. S. (2013). Using multivariate statistics (Sixth edition). United States: Pearson Education. 
Turan Gürhopur, F. D. ve İşler Dalgıç, A. (2017). Zihinsel Yetersiz Çocuğu Olan Ebeveynlerde Aile Yükü. /Psikiyatri Hemşireliği Dergisi, 8(1), 9-16

Uskun, E. ve Gundogar, D. (2010). The levels of stress, depression and anxiety of parents of disabled children in Turkey. Disability and Rehabilitation, 32(23), 1917-1927

Wang, Y., Huang, Z. ve Kong, F. (2017). Parenting stress and life satisfaction in mothers of children with cerebral palsy: The mediating effect of social support. Journal of Health Psychology, 1-10

Yıldırım, A., Aşılar, R. H. ve Karakurt, P. (2013). Engelli çocukların annelerinin ruhsal durumlarmn belirlenmesi. Florence Nightingale Hemşirelik Dergisi, 20(3), 200209

Yıldırım, F. ve Conk, Z. (2005). Zihinsel yetersizliği olan çocuğa sahip anne/babaların stresle başa çıma tarzlarına ve depresyon düzeylerine planlı eğitimin etkisi. Cumhuriyet Üniversitesi Hemşirelik Yüksekokulu Dergisi, 9(2), 1-10.

\section{Kaynakça Bilgisi / Citation Information}

Cengiz, S., Nebioğlu Yıldız, M. ve Peker, A. (2021). Özel gereksinimli çocuğa sahip ebeveynler ile tipik gelişim gösteren çocuğa sahip ebeveynlerin stres ve yaşam doyum düzeylerinin incelenmesi. OPUS-Uluslararası Toplum Araştırmaları Dergisi, 17(36), 2940-2956. DOI: 10.26466/opus. 832440 